\title{
Institutional Inefficiencies in Latin America
}

\author{
Panagiotis Evangelopoulos \\ Department of Economics, University of Peloponnese, Tripolis, Greece \\ Email: panevans@uop.gr
}

Received July 25, 2012; revised August 27, 2012; accepted September 28, 2012

\begin{abstract}
In North America the establishment of the institutions of individual liberty and free enterprise demonstrate that prosperity is a function of freedom. Diametrically opposite, Latin America has throughout its history been required to endure attempts at imposing collectivist institutions. The new institutional economic historian approach implies that poor economic performance is attributable to the inefficient institutional framework. Based on this analysis I explain the reasons of the wealth differences between North and Latin America.
\end{abstract}

Keywords: Individual Liberty; Free Enterprise; Collectivism; Economic Development

\section{Introduction}

Latin America has throughout its history been required to endure attempts at imposing collectivist institutions, resulting in a type of poor economic performance comprised of sluggish development, blatant inequalities in the distribution of wealth, widespread poverty, antiproductive and stagnating distribution of huge reserves of wealth, all of which when taken together lead to an idiosyncratic social regime lacking the capacity to administer a fantastic earthly paradise. Since its discovery and throughout the modern era the Spanish ${ }^{1}$ [1] and Portuguese conquerors, in a number of different guises, adventurers, conquistadors, Catholic missionaries, official plenipotentiaries of the royal courts, established feudal collectivism throughout the length and breadth of Latin America, with conspicuous features of a stagnant serfdom, immobilizing the social dynamic and paralysing economic growth through all its history up until the present day.

\section{Comparative Analysis between North and Latin America}

The diametrically opposite approach was pursued in North America ${ }^{2}[2,3]$. Albeit poorer in productive re-

\footnotetext{
${ }^{1}$ North \& Thomas (1973, p. 131) [1] "It is true that Spain attempted to dominate the Western World and failed, but it tried to do so with foreign revenues. Spain itself provided only about 10 percent of the empire's revenues at its height. Its economy remained medieval throughout its bid for political dominance $\cdots$ Spain provides an excellent example of the results and consequences of failing to develop an efficient economic organization.”

${ }^{2}$ As Peter Temin comments (1973, p. 9) [3] the work of P. A. David (1967) [2] "The record as reconstructed showed that the origins of the high American standard of living antedated the beginning of industrialization and that there is no evidence of a discontinuity in the rate of economic growth in the early nineteenth century.”
}

sources, the first settlers, with Anglo-Saxons ${ }^{3}[1,4]$ the predominant element, adopted individualistic institutions $^{4}[1]$, the free market, property rights, the rule of law, democratic representation and polycentric exercise and control of political power ${ }^{5}$ [5]. This was the touchstone for the success of a poorer North America as against a more resource-rich Latin America ${ }^{6}$ [6]. The institutions of individual liberty and free enterprise, the civilization of a flourishing open community, counteracted the disadvantages of a more adverse geophysical situation, demonstrating that prosperity is a function of freedom, the most precious patrimony than can be bestowed upon a human being during his sojourn upon this earth.

This success, underwritten by individualistic institutions, as opposed to the ruin to which we are led by the embrace of collectivism, was indisputably animated by

\footnotetext{
${ }^{3}$ In North America Anglo Saxons follow the same model from their experience in England in sixteenth century. North \& Thomas (1973, p. 152) [1] explain that in England in sixteenth century. "Technological change remained of minor importance. The gains made in industry, like those in agriculture, were due to the achievement of a more efficient set of property rights in both factor and product markets.” With this seminal North's argument, it is similar the Fogel's [4] major contribution in his path breaking article (1962). Fogel concludes that is not simply the new technology of railroads that caused the economic growth of the USA in nineteenth century.

${ }^{4}$ North \& Thomas (1973, p. 157) [1] "Capitalism required the development of efficient property rights, to make it the remarkable engine of progress which was necessary for this process."

${ }^{5}$ North (1981, p. 187) [5] "The American colonies were in the extraordinary position of taking over from England not only the body of property rights (and common law) that had been evolving there, but also the deep distrust of a powerful state that emerged from the English Revolution.”

${ }^{6}$ North (1990) [6] forms a unified institutional economic historian approach that proves how efficient institutional frameworks achieve successful economic performance.
} 
the work of the economist Douglass North ${ }^{7}[1,5,6]$, who in his work presents us with a fully documented dissertation demonstrating the historical success of systems of social organization in which the prime mover and key protagonist is the individual, as opposed to collective structures. Based on North's work, insight and contribution, we can analyse the failure of Latin America ${ }^{8}$ [1] and we can make great strides towards application of the new economic historian institutional method ${ }^{9}[7,8]$ to explain the impasses and the deadlock into which this resourceprivileged region has been led.

Marked by its discovery by feudalistic collectivism, Latin America even in the twentieth century when its first independent states were established opted to persist with failed collectivist organizational schemes ${ }^{10}$ [9]. The insatiable populism of a Peron, the ponderous socialism of an Allende, the armour-clad Communism of a Castro, not to mention the naivety of Che-Guevara-style permanent revolution, all variants on a collectivist compendium of idea and principles that dragoon the individual into a forced march under the direction of societies that identify themselves with, or have been subordinated to, the arbitrary rule of an uncontrolled and uncontrollable leader. Their only legitimation derives from the notion that they express society as a whole, that they, and only they, truly represent the people. Every other view different from their own is instigated by enemies of the people, against the people.

In Latin America in our day the same bankrupt leadership model is being reproduced. With Chavez as it characteristic paradigm and its political guide, Latin America is being conducted along the path to a new failure that will plunge it even deeper into the morass of poverty and arbitrary rule. Chavez' power is growing ever more imperial, carried out by personal edict, gradually eliminating the liberties preserved by his country's pluralistic institutions. In the economic field he is fol-

\footnotetext{
${ }^{7}$ Douglass North is undoubtedly the protagonist of this contribution who showed (North \& Thomas, 1973) [1] that the rise and success of the western world historically was based on prevailing institutions of individual liberty, free enterprise and secure property rights.

${ }^{8}$ North \& Thomas (1973, p. 157) [1] "The failures - the Iberian Peninsula in the history of the Western World, and much of Latin America, Asia and Africa in our times-have been a consequence of inefficient economic organization.”

${ }^{9}$ On this direction is the pioneering work of Hernando de Soto (2003) [7] that gives the most powerful and convincing approach of the application of property rights for promoting economic development, rule of law and freedom in Third World and ex-communist countries (Soto, 2006) [8].

${ }^{10}$ As Mancur Olson (1982, p. 165) [9] explains for the countries of Latin America "The characteristically unstable countries are usually governed part of the time by dictators or juntas; they have intervals of democratic or at least relatively pluralistic government. The policies of the dictators or the juntas obviously will depend dramatically on the interests, the ideology, and sometimes even the whims of the dictator or the leadership group."
}

lowing the road of absolute personal control under the mantle of socialization. The oil that is his country's patrimony is falling prey to his international political ambitions. He loves to assert that he distributes it to the poor of the United States and other countries when poverty in his own country is ravaging city and countryside alike. In a few years when his nationalized oil wells and mines will need the investments and new technical expertise that his bureaucratic, populist, and monolithic socialist party power will be unable to provide, again he will have to resort both to international lending from the global capitalist markets and direct foreign investment and technical aid from the global petroleum companies or even to importing petrol ${ }^{11}$ from them. The irrational and inefficient collectivist model of Chavez is already visible elsewhere in the economy with the frightful shortages of goods in the supermarkets of Venezuela owing to his bureaucratic regulated policy of the last four years of freezing prices by decree. Instead of perceiving his mistake he has chosen to compound it by planning for nationalization of the supermarkets and more.

Chavez and his growing band of imitators in Latin America are extending the collectivist model, justifying their failures to their peoples with the argument that they are being undermined by the United States. It is the easy, makeshift solution chosen by all wielders of arbitrary power, the attribution of their failure to the actions of their enemies. The truth is that Chavez is writing the requiem to the collectivist leadership model in Latin America.

The new institutional economic historian methodology is being widely applied in Latin America. Both formal and informal rules entail the modern institutional framework in Latin America that is characterized—at present and in its historical past - by a progressive accumulation of inefficient political, social and economic structures. The institutional rules, either formal or informal, that predominate in Latin America bear the stamp of one man/one leader arbitrary rule and the monopoly of the power. They are expressed socially through a modern populist feudalism, and embodied economically in a state collectivism. The new institutional economic historian methodology puts forward the thesis that poor or negative economic performance, social immiseration and the monopolization of political power are all attributable to the inefficient institutional framework.

\section{Conclusion}

Applying the new method to each country in Latin America we can extract crucial insights into the level of economic development, the ambit of social welfare and

\footnotetext{
${ }^{11}$ I take the opportunity to paraphrase the euphemistic quotation of Milton Friedman "If you put the federal government in charge of the Sahara Desert, in 5 years there'd be a shortage of sand.”
} 
the kind of political power being exercised. If we categorize the countries of Latin America on basis of a taxonomy of progress in establishing free institutions, property rights, free enterprise, a free market, the rule of law and polycentric democracy, we are enabled to arrive at a perspective whereby the countries of Latin America that advance their prosperity and freedom and those that remain stagnant before regressing into a fatal collapse, are respectively identified. The application of the new institutional economic historian method to the countries of Latin America explains the wealth differences with North America and shows clearly the policy reforms from the collectivist institutions to the individualist institutions for a successful economic performance, social harmony and democratic consolidation in a constitutional environment of open and free society.

\section{REFERENCES}

[1] D. C. North and R. Thomas, "The Rise of the Western World: A New Economic History,” Cambridge University Press, Cambridge, 1973. doi:10.1017/CBO9780511819438
[2] P. A. David, "New Light on a Statistical Dark Age: US Real Product Growth before 1840," American Economic Review, Vol. 57, No. 2, 1967, pp. 294-306.

[3] T. Peter, “New Economic History,” Penguin Books Ltd., Harmondsworth, 1973.

[4] R. W. Fogel, "A Quantitative Approach to the Study of Railroads in American Economic Growth: A Report of some Preliminary Findings," Journal of Economic History, Vol. 22, No. 2, 1962, pp. 163-197.

[5] D. C. North, "Structure and Change in Economic History,” W. W. Norton, New York, 1981.

[6] D. C. North, "Institutions, Institutional Change and Economic Performance,” Cambridge University Press, Cambridge, 1990. doi:10.1017/CBO9780511808678

[7] H. de Soto, “The Mystery of Capital,” Basic Books, New York, 2003.

[8] H. de Soto, “The Challenge of Connecting Informal and Formal Property Systems. Some Reflections Based on the Case of Tanzania,” In: H. de Soto and F. Cheneval, Eds., Realizing Property Rights, Rüffer and Rub, Zurich, 2006, pp. 18-67.

[9] M. Olson, “The Rise and Decline of Nations," Yale University Press, New Haven and London, 1982. 